\title{
Estimating turnover rates of carbon and nitrogen in recently metamorphosed winter flounder Pseudopleuronectes americanus with stable isotopes
}

\author{
Keith L. Bosley ${ }^{1,2, *}$, David A. Witting ${ }^{3}$, R. Christopher Chambers ${ }^{3}$, Sam C. Wainright ${ }^{2, * *}$ \\ ${ }^{1}$ Fishery Resource Analysis and Monitoring Division, National Marine Fisheries Service, Northwest Fisheries Science \\ Center, Hatfield Marine Science Center, 2030 S.E. Marine Science Drive, Newport, Oregon 97365, USA \\ ${ }^{2}$ Rutgers University Institute of Marine and Coastal Sciences, 71 Dudley Road, New Brunswick, New Jersey 08901-8521, USA \\ ${ }^{3}$ Coastal Ecology Branch, National Marine Fisheries Service, Northeast Fisheries Science Center, 74 Magruder Road, \\ Highlands, New Jersey 07732, USA
}

\begin{abstract}
Stable-isotope ratios of carbon $\left({ }^{13} \mathrm{C} /{ }^{12} \mathrm{C}\right)$ and nitrogen $\left({ }^{15} \mathrm{~N} /{ }^{14} \mathrm{~N}\right)$ are widely used in the analysis of animal diets. However, using these stable-isotope ratios to infer dietary changes depends on precise knowledge of turnover rates of carbon and nitrogen. In the present study, carbon and nitrogen turnover rates were determined for recently settled juvenile winter flounder Pseudopleuronectes americanus in the laboratory using naturally occurring stable isotopes as dietary tracers. Flounder were reared at $13^{\circ} \mathrm{C}$ on a diet of rotifers Brachionus plicatilis of known isotopic composition from the time that the larvae began feeding until they reached metamorphosis and began to settle to the benthic habitat. At settlement, the fish were assigned to 1 of 2 temperature treatments $(13$ and $18^{\circ} \mathrm{C}$ ). A subset of fish at each temperature was maintained on rotifers to serve as controls. The remaining fish were switched to a diet of brine shrimp Artemia sp. (known to be isotopically distinct from rotifers) and then sampled systematically over a $16 \mathrm{~d}$ period. Temperature had a significant effect on both carbon and nitrogen turnover rates. At $13^{\circ} \mathrm{C}$, the half-life of carbon was $4.1 \mathrm{~d}( \pm 0.6)$, and of nitrogen, $3.9 \mathrm{~d}( \pm 0.7)$. At $18^{\circ} \mathrm{C}$, the half-life of carbon was $2.2 \mathrm{~d}( \pm 0.3)$, and of nitrogen, $3.1 \mathrm{~d}$ $( \pm 0.3)$. The change in isotopic composition closely followed predictions based entirely on the production of new tissue.
\end{abstract}

KEY WORDS: Stable isotopes · Diet shifts · Pseudopleuronectes americanus · Winter-flounder habitat · Temperature

Resale or republication not permitted without written consent of the publisher

\section{INTRODUCTION}

Knowledge of the identity and sources of prey consumed by fishes is fundamental to understanding trophic relationships in most aquatic ecosystems. One complication that makes this difficult is the fact that

\footnotetext{
*E-mail: keith.bosley@noaa.gov

${ }^{* *}$ Present address: Department of Science, United States Coast Guard Academy, 15 Mohegan Avenue, New London, Connecticut 06320-8100, USA
}

fish are likely to encounter complex assemblages of prey (Checkley 1982, Peterson \& Ausubel 1984, Jenkins 1987, Perry \& Neilson 1988, McLaren \& Avendano $1995)$ which may vary with life stage (Grover et al. 1998). Another is the difficulty in quantifying the relative importance of prey items beyond simply the frequency of the occurrence of prey items in the stomach of a fish. The extent that behavioral and physiological responses of a fish to its environment may be affected by spatial and temporal variability of different environmental factors also makes identifying trophic relation- 
ships more difficult. A better knowledge of the ways in which the identity, sources and value of a fish's diet may be manifested and the rates at which changes in diet are expressed in a fish's tissues, as well as how both of these may vary with environmental factors such as water temperature, is essential for gaining a clearer understanding of trophic relationships in aquatic ecosystems.

Naturally occurring stable isotopes of carbon and nitrogen have proven to be useful tools for identifying sources of nutrition as well as trophic relationships in food webs (reviews by Fry \& Sherr 1984, Owens 1987, Peterson \& Fry 1987). This is because the manner in which the stable-isotopic composition of a consumer's tissues reflects its diet is fairly predictable (DeNiro \& Epstein 1978, 1981, McConnaughey \& McRoy 1979, Rau et al. 1983, Minigawa \& Wada 1984, Fry 1988). An assumption that is sometimes made in stableisotope studies is that the diet of an animal is constant, or that the animal is in equilibrium with its diet, i.e. the time since the most recent diet change is greater than the time required for tissues to attain the value that reflects the new diet. However, if the diet of a consumer changes through time, a knowledge of the amount of time required for the isotopic composition of a consumer to equilibrate with the isotopic composition of its current diet is essential if information on recent diet is to be inferred from the isotopic composition of the consumer. Recent studies have used stable isotopes to examine food-web interactions and fish migration (Hansson et al. 1997) and to document the settlement history of individual fish larvae into demersal habitats (Herzka et al. 2001). These studies illustrate how, with good estimates of the length of time required for the isotopic composition of fish tissue to reflect its diet, stable-isotope ratios are better tools for inferring changes in diet which may, in turn, reflect changes in the foraging behavior of animals or the habitats that they occupy. Ecological applications of stable-isotope techniques will be enhanced by experimental or laboratory validation of the assumptions that are made when they are used in a field context (Gannes et al. 1997).

Changes in the isotopic composition of tissues after a change in diet occurs through 2 processes. The first process involves the metabolic breakdown, or turnover, of tissues that were synthesized during feeding on a previous diet, and their subsequent replacement with tissues synthesized on a new diet (Hobson \& Clark 1992, Hesslein et al. 1993). Secondly, the growth of new tissues that occurs after a diet switch will also reflect the isotopic composition of the current diet (Fry \& Arnold 1982, Herzka \& Holt 2000), and therefore will contribute to the overall reflection of that diet in the isotopic composition of the consumer. Taken together, these processes result in a change in the isotopic composition of fish tissues after a change in diet.

Changes in the isotopic composition of tissues over time provide a means of estimating turnover rates because ratios of stable isotopes of carbon and nitrogen in tissues reflect the integration of dietary carbon or nitrogen assimilated by a consumer. Controlledfeeding experiments using 2 or more isotopically distinct prey species can be used to determine the time required for a diet shift to be reflected in the isotopic composition of the consumer's tissues. The determination of turnover rates in non-growing organisms, typically referred to as metabolic turnover, can be made by simply monitoring the isotopic composition of body tissues as a function of the time after the shift to an isotopically distinct diet (Tieszen et al. 1983, Hobson \& Clark 1992). In growing organisms, however, the amount of somatic growth that occurs after the diet shift must be accounted for as well, so turnover rates are determined by monitoring the isotopic composition of body tissues as a function of growth. In growing organisms, therefore, the rate at which the turnover of older tissues occurs can be determined by the difference between the observed change in isotopic composition relative to growth and the change predicted from growth alone (Fry \& Arnold 1982, Hesslein et al. 1993, Herzka \& Holt 2000).

Previous determinations of the turnover rates of tissues using stable-isotope methods have used various ectotherm and endotherm taxa as study subjects, including post-larval brown shrimp Penaeus aztecus (Fry \& Arnold 1982), gerbils Meriones unguienlatus (Tieszen et al. 1983), Japanese quail Coturnix japonica (Hobson \& Clark 1992), broad whitefish Coregonus nasus (Hesslein et al. 1993), and larval red drum Sciaenops ocellatus (Herzka \& Holt 2000). The results of those studies suggest that turnover rates are specific to the taxon and tissue being analyzed.

Turnover rates may vary during an organism's life such that an organism that is growing or developing rapidly will have a more rapid turnover rate than one that is growing less rapidly or not at all. For instance, Fry \& Arnold (1982) found that rapidly growing postlarval brown shrimp Penaeus aztecus had higher carbon turnover rates than shrimp that grew more slowly. Furthermore, tissues and body components that have a high level of metabolic activity such as blood, or that possess a high lipid content such as liver, are known to have more rapid turnover rates than less active ones such as bone collagen, or less fatty ones such as hair (Tieszen et al. 1983, Hobson \& Clark 1992). Regarding tissue-specificity, Hobson \& Clark found that turnover rates in quail were the most rapid for liver (half-life ca. $2.6 \mathrm{~d}$ ), followed by blood (ca. $11.4 \mathrm{~d}$ ), muscle (ca. $12.4 \mathrm{~d}$ ), and bone collagen (ca. $173.3 \mathrm{~d}$ ). 
Turnover rates are typically expressed in terms of half-life. Half-life refers to the amount of time required for the stable-isotopic signature of the consumer's tissue to reach a midpoint value between that observed with the original diet and that which will be observed with the new diet in equilibrium. The half-lives estimated in previous studies ranged from $\sim 2 \mathrm{~d}$ for reddrum larvae to $>1$ yr for adult broad whitefish. Previous investigations have also revealed that the time required for tissues of juvenile fishes to reflect a diet shift is rapid relative to the time required by adult fishes, presumably reflecting the rapid growth of the juveniles (Bosley 1998).

The effect of temperature on turnover rate is unclear, although a direct relationship might be expected given the well-established direct relationship between temperature and growth (Brown 1957). Therefore, considering the range of seasons (and temperatures) over which different species of fishes (and even different individuals within a species of fish: Chambers 1997) spawn, there is potential for substantial temperatureinduced variability in turnover rates. Winter flounder typically settle from late April to early June in New Jersey estuaries, and the temperatures that they may experience during these months range from about 10 to $20^{\circ} \mathrm{C}$ (Witting 1995). Herzka \& Holt (2000) reared larval red drum at 2 temperatures, but they did not address the effect of temperature on turnover rates.

This study experimentally determines the turnover rates of carbon and nitrogen, and the effects of water temperature on these rates, in juvenile winter flounder Pseudopleuronectes americanus. The subjects that were used were laboratory-reared fish of known age and feeding history. At the start of the study, the flounder were consistently expressing benthic behavior and were undergoing metamorphosis from the pelagic larval stage, i.e. larvae were Stage G of Minami (1982). The metamorphosis of flounder in nature also is associated with their transition from pelagic to benthic habitats, which is likely to result in a change of diet. Although the transition is rapid for individual fish, differences in spawning times and locations of larvae will result in substantial variations in water temperatures experienced by individual fish at the time of their diet shifts in habitats. Hence, this experimental model does pertain to diet changes and water- temperature variations experienced by flounder in nature.

\section{MATERIALS AND METHODS}

Fish culture and rearing. Winter-flounder gametes were obtained from adults collected in Logy Bay, Newfoundland, Canada, by the staff at the Ocean Sciences Centre, Memorial University of Newfoundland. The eggs were fertilized, maintained at $<5^{\circ} \mathrm{C}$, and sent within $1 \mathrm{~d}$ to the National Oceanic and Atmospheric Administration's Howard Laboratory, Highlands, New Jersey, USA. There they were incubated until hatching under static conditions at $5^{\circ} \mathrm{C}$ and a light cycle of $12 \mathrm{~h}$ light:12 $\mathrm{h}$ dark. The embryos were maintained in filtered, UV-sterilized seawater which was changed daily during the period from fertilization through hatching ( $3 \mathrm{wk})$. Upon hatching, 1000 larvae $(<1 \mathrm{~d}$ old) were counted, placed into a 601 , cylindrical, rearing container, and maintained at $13^{\circ} \mathrm{C}$ under static conditions. These larvae were fed a daily augmentation of rotifers Brachionus pilcatilis (5 rotifers $\mathrm{ml}^{-1}$ ). The rotifers themselves were cultured separately from the fish and were fed a mixture of unicellular marine algae (Dunaliella tertiolecta, Isochrysis galbana, and the University of Texas-2341 strain of Nannochloropsis oculata).

The experimental laboratory approach by which metamorphosing winter flounder underwent a diet shift from rotifers to Artemia sp. is shown in Table 1. These prey species were chosen because both are readily eaten by winter flounder of this age, and they were determined previously to be isotopically distinct from one another (Table 2). At the onset of eye migration (an indicator of metamorphosis in flatfishes), 96 fish were videotaped live at $6 \times$ magnification for later size determination. Of these fish, 12 were frozen $\left(-20^{\circ} \mathrm{C}\right)$ to provide initial stable-isotopic-composition values of winter flounder after feeding exclusively on rotifers. The remaining 84 fish were distributed at 2 fish per container into $42 \times 81$ containers of filtered, UV-treated seawater. The containers were divided equally between the 2 test temperatures, 13 and $18^{\circ} \mathrm{C}$. These temperatures were selected because they are representative of the temperatures that recently settled winter flounder might encounter in New Jersey estuaries (Witting 1995).

Table 1. Pseudopleuronectes americanus. Experimental design for a controlled diet shift to derive carbon and nitrogen turnover rates in juvenile winter flounder. Fish were sampled at time $\left(t_{i}\right) 0,1,2,4,8$, and $16 \mathrm{~d}$ after the diet switch from the rotifer Brachionus pilcatilis to the brine shrimp Artemia sp. Numbers listed under each sampling time refer to the number of fish. Each sample consisted of 2 winter flounder from each of 3 containers; the $t_{0}$ sample was a single collection of 12 flounder from the source-rearing container

\begin{tabular}{|lccccccccc|}
\hline \multirow{2}{*}{ Diet } & \multirow{2}{*}{$T\left({ }^{\circ} \mathrm{C}\right)$} & \multicolumn{8}{c|}{ Sample size at $t_{\mathrm{i}}$} \\
& & $t_{0}$ & $t_{1}$ & $t_{2}$ & $t_{4}$ & $t_{8}$ & $t_{16}$ & $\sum t_{\mathrm{i}}$ \\
\hline Rotifers & 13 & 12 & - & - & - & 6 & 6 & 24 \\
& 18 & - & - & - & - & 6 & 6 & 12 \\
Artemia sp. & 13 & - & 6 & 6 & 6 & 6 & 6 & 30 \\
& 18 & - & 6 & 6 & 6 & 6 & 6 & 30 \\
& & & & & & & & & \\
\end{tabular}


Table 2. Nitrogen and carbon stable-isotopic composition of the fish diets and algal supplements used in the turnover experiment. Fish diet samples were taken 0, 8 (except for Artemia sp.), and $16 \mathrm{~d}$ after the start of the experiment. Algal samples were taken at the end of the experiment. Units are per mil (\%)

\begin{tabular}{|c|c|c|c|c|c|c|}
\hline \multirow[t]{2}{*}{ Sample } & \multicolumn{6}{|c|}{ Isotopic value } \\
\hline & $\delta^{15} \mathrm{~N}$ & $t_{\delta^{13} \mathrm{C}}$ & $\delta^{15} \mathrm{~N}$ & ${ }^{t_{8}} \delta^{13} \mathrm{C}$ & $\delta^{15} \mathrm{~N}$ & ${ }^{16} \delta^{13} \mathrm{C}$ \\
\hline \multicolumn{7}{|l|}{ Fish diets } \\
\hline Brachionus plicatilis & -7.97 & -14.91 & -8.73 & -13.17 & -3.44 & -14.15 \\
\hline Artemia sp. & 13.53 & -21.76 & - & - & 12.80 & -22.06 \\
\hline \multicolumn{7}{|l|}{ Algae } \\
\hline Dunaliella tertiolecta & & & & & -3.79 & -16.44 \\
\hline Isochrysis galbana & & & & & -0.08 & -16.49 \\
\hline Nannochloropsis ocul & & & & & 3.65 & -12.93 \\
\hline
\end{tabular}

Samples of the diets were also collected throughout the experiment and frozen until processing for stableisotope analyses. Rotifer samples were collected at Times $t_{0}, t_{8}$, and $t_{16}$, and Artemia sp. were sampled at $t_{0}$ and $t_{16}$. Samples (100 ml each) of algae-rich water from the culture containers were filtered through pre-combusted, glassfiber filters (Whatman GF/F) and then frozen until further processing for stable-isotope analyses.

Sample preparation for isotopic analysis. In order to obtain final dry weights of the fish, each individual was rinsed with deionized water, loaded

The fish in 6 containers at each temperature $(n=24$ total fish) were maintained on the original diet of algae-enriched rotifers (5 rotifers $\mathrm{ml}^{-1} \mathrm{~d}^{-1}$ ). For each temperature, 3 containers were sampled at $8 \mathrm{~d}$, and 3 more at $16 \mathrm{~d}$ after the start of the experiment. The fish were videotaped live for later size determination and then frozen.

The remaining fish $(\mathrm{n}=60)$ were switched to a diet of Artemia sp. (1 Artemia ml $\mathrm{m}^{-1} \mathrm{~d}^{-1}$ ). Fish in 3 containers in each temperature treatment were videotaped and then frozen at times $\left(t_{i}\right) 1,2,4,8$, and $16 \mathrm{~d}$ after the diet switch.

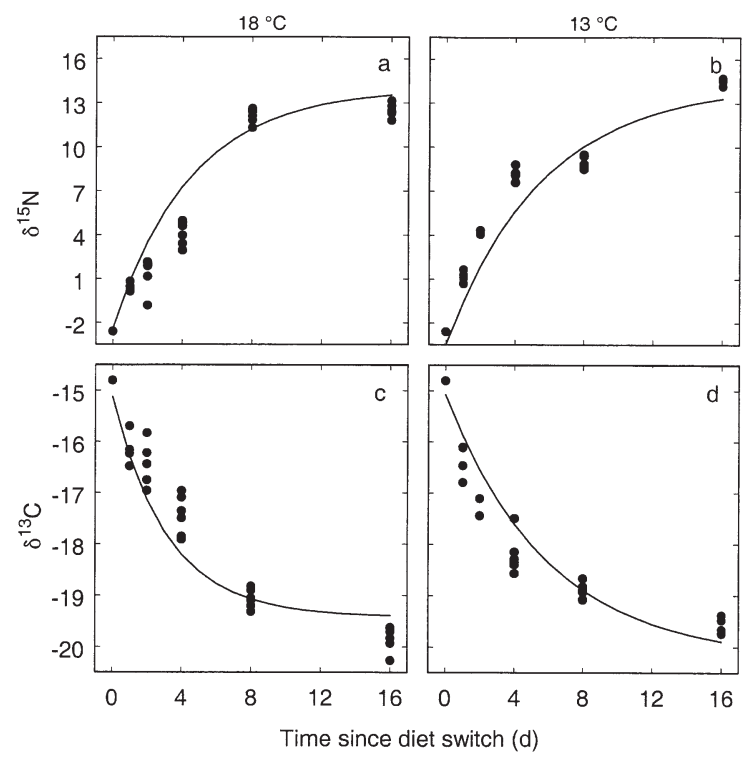

Fig. 1. Pleuronectes americanus. Nitrogen stable-isotope value, $\delta^{15} \mathrm{~N}(\mathrm{a}, \mathrm{b})$, and carbon stable-isotope value, $\delta^{13} \mathrm{C}(\mathrm{c}, \mathrm{d})$, of individual winter flounder as a function of the time since their diet was switched from rotifers Brachionus plicatilis to Artemia sp. Fish were maintained at $18(\mathrm{a}, \mathrm{c})$ or $13^{\circ} \mathrm{C}(\mathrm{b}, \mathrm{d})$. Lines represent the best-fit nonlinear regressions to the data, using the model of Hobson \& Clark (1992) into a pre-weighed $8 \times 5 \mathrm{~mm}$ tin capsule (Microanalysis), and placed in a $55^{\circ} \mathrm{C}$ drying oven for $24 \mathrm{~h}$. After drying, the tin capsules were reweighed (Sartorius Micro Balance ${ }^{\mathrm{TM}}$ ), and the final dry weight of each fish was determined by difference. The capsules were crushed into small balls and stored in a desiccator until analysis. A regression between length and dry weight $\left(\mathrm{r}^{2}=0.81\right)$ of the $12 t_{0}$ fish was used to estimate the initial dry weights of all of the fish destructively sampled at times subsequent to $t_{0}$. (All fish were videotaped for lengths prior to the experiment and at the time of sacrifice.) The initial dry weights of the $12 t_{0}$ fish and the measured final dry weights of all fish were then used to estimate the amount of growth in dry weight for each fish.

Samples of rotifers and Artemia sp. were placed into pre-combusted glass vials and dried at $55^{\circ} \mathrm{C}$ for $24 \mathrm{~h}$ or until completely dried. After drying, these subsamples were ground to a fine powder using a Wig-L-Bug ${ }^{\mathrm{TM}}$ (Crescent Dental) automated mortar and pestle. Approximately $0.8 \mathrm{mg}$ of sample was loaded into tin capsules for analysis.

The filters upon which the algae were collected were thawed and rinsed with deionized water. Algae (plus some filter material) was scraped from the filters, placed into pre-combusted glass vials, and dried at $55^{\circ} \mathrm{C}$ for $24 \mathrm{~h}$. After drying, the material was ground using a clean glass mortar and pestle. Approximately $5 \mathrm{mg}$ of each sample were loaded into tin capsules for analysis.

Sample analysis. The stable-isotope analysis was carried out using a Europa Scientific ANCA-GSL elemental analyzer coupled to a Europa Scientific 20/20 stable-isotope ratio mass spectrometer in the continuous-flow mode, with ultra-high-purity helium as the carrier gas. The stable-isotope ratios $\left({ }^{15} \mathrm{~N}:{ }^{14} \mathrm{~N}\right.$ and ${ }^{13} \mathrm{C}:{ }^{12} \mathrm{C}$ ) are reported as $\delta^{15} \mathrm{~N}$ and $\delta^{13} \mathrm{C}$, with units of per mil (\%) difference relative to standards $\left(\mathrm{N}_{2}\right.$ in air for nitrogen and the fossil Belemnitella americana [PDB] 
Table 3. Pseudopleuronectes americanus. Estimates of turnover constants $(C)$ calculated using nonlinear regressions of carbon and nitrogen stable-isotope data vs time since diet switch from rotifers Brachionus plicatilis to Artemia sp. Halflives calculated from the turnover constants are included. Turnover rates of both carbon and nitrogen were significantly faster at 18 than at $13^{\circ} \mathrm{C}(\mathrm{p}<0.001$ for both, Student's $t$-test)

\begin{tabular}{|lccc|}
\hline Element & $T\left({ }^{\circ} \mathrm{C}\right)$ & $C( \pm \mathrm{SE})$ & Half-life $(\mathrm{d})$ \\
\hline$\delta^{13} \mathrm{C}$ & 13 & $-0.17 \pm 0.024$ & 4.1 \\
& 18 & $-0.32 \pm 0.038$ & 2.2 \\
$\delta^{15} \mathrm{~N}$ & 13 & $-0.18 \pm 0.032$ & 3.9 \\
& 18 & $-0.22 \pm 0.038$ & 3.1 \\
\hline
\end{tabular}

from the Peedee formation of South Carolina [Craig 1957] for carbon). Secondary standards (egg powder and aquatic plant) were included in each batch for quality control. The average values of the secondary standards for the 2 elements indicated that the isotopic determinations were close to the expected values. The standard deviation around the expected values for the secondary standards was $\pm 0.3 \%$ o $(\mathrm{n}=2$ secondary standards for every 10 unknowns analyzed).

Estimating turnover rates. Turnover rates were calculated in 2 ways. Turnover rate as a function of the time since the diet switch was determined by the exponential model of Hobson \& Clark (1992), using the equation:

$$
y=a+b \mathrm{e}^{c t}
$$

where $y=\delta^{13} \mathrm{C}$ or $\delta^{15} \mathrm{~N}$ at Time $t, a=$ the value being approached asymptotically, $b=$ the total change in isotope value after the diet is switched, $c=$ the turnover rate, and $t=$ the time since the diet switch.

Second, turnover rate as a function of the change in weight since the diet switch was determined by the exponential model of Fry \& Arnold (1982). This model defines growth as the increase in individual mass relative to initial mass (measured here as dry weight):

$$
W_{\mathrm{R}}=W_{\mathrm{f}} / W_{\mathrm{i}}
$$

where $W_{\mathrm{R}}=$ growth relative to initial weight, $W_{\mathrm{f}}=$ final weight, and $W_{\mathrm{i}}=$ initial weight. This estimate of growth can then be used to yield an estimate of growth-specific turnover with the equation:

$$
y=a+b W_{\mathrm{R}}^{c}
$$

in which the variables are the same as in Eq. (1). In this model, growth is entirely responsible for the change in isotopic composition if $c=-1$. If $c<-1$, metabolic turnover or replacement of old tissues is occurring, with more negative values of $c$ corresponding to higher turnover rates. Derivations of the models and equations used to calculate half-lives are in the original literature references. The estimates of $c$ were obtained from a Levenburg-Marquardt iterative, non-linear, least-squares fitting algorithm (Seber \& Wild 1989), with software (TableCurve 2D ${ }^{\mathrm{TM}}$ ) specifically designed for this purpose.

\section{RESULTS}

The controlled laboratory conditions resulted in clear, temporal patterns that showed changes in the isotopic composition of the fish (Fig. 1). The estimates of turnover rates calculated using time since the diet switch as the independent variable and the corresponding half-lives varied significantly among the temperatures tested (Table 3). The turnover of both carbon and nitrogen was significantly faster at $18^{\circ} \mathrm{C}$ than at $13^{\circ} \mathrm{C}(\mathrm{p}<0.001$ for both, Student's $t$-test). However, it appears that the model may be overestimating the turnover rates at $18^{\circ} \mathrm{C}$ and underestimating the turnover rates at $13^{\circ} \mathrm{C}$ over the $4 \mathrm{~d}$ immediately following the diet change (Fig. 1).

By also examining changes in both the nitrogen- and carbon-isotopic compositions relative to growth (Fig. 2), it was determined that at both temperatures the expo-

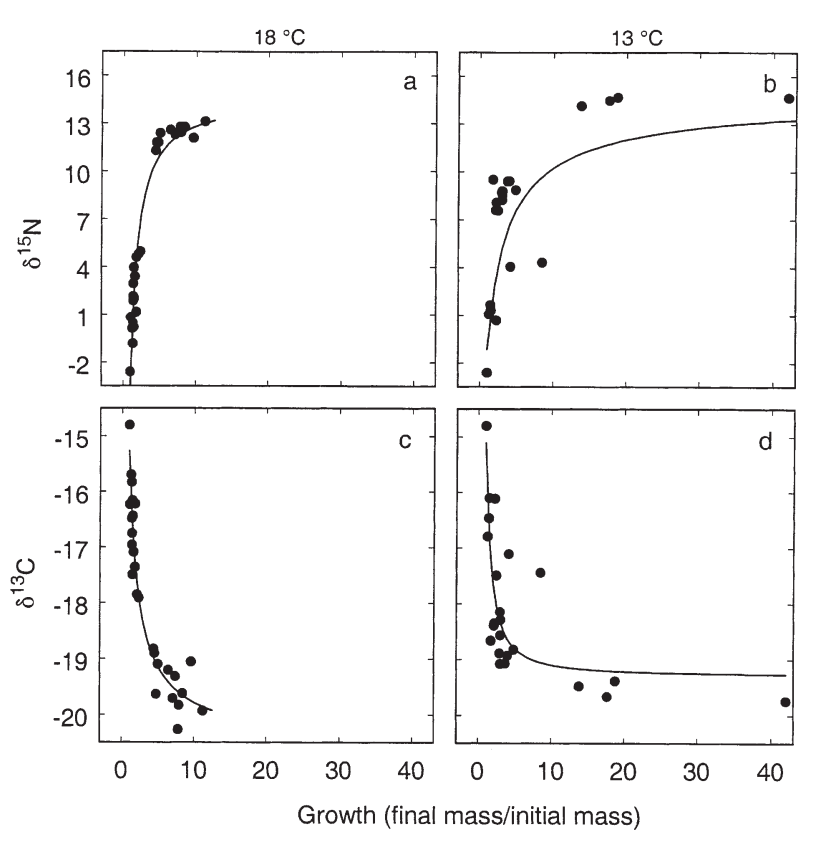

Fig. 2. Pleuronectes americanus. Nitrogen stable-isotope value, $\delta^{15} \mathrm{~N}(\mathrm{a}, \mathrm{b})$, and carbon stable-isotope value, $\delta^{13} \mathrm{C}(\mathrm{c}, \mathrm{d})$, of individual winter flounder as a function of growth (relative increase in individual dry weight) since their diet was switched from rotifers Brachionus plicatilis to Artemia sp. Fish were maintained at $18(\mathrm{a}, \mathrm{c})$ or $13^{\circ} \mathrm{C}(\mathrm{b}, \mathrm{d})$. Lines represent the bestfit nonlinear regressions to the data, using the model of Fry \& Arnold (1982) 
Table 4. Pseudopleuronectes americanus. Estimates of turnover constants $(C)$ calculated using nonlinear regressions of carbon and nitrogen stable-isotope data vs growth since the diet switch from rotifers (Brachionus plicatilis) to Artemia $\mathrm{sp}$. The values of $\mathrm{r}^{2}$ indicate the fit of the Fry \& Arnold (1982) model to the data. The $t$-statistic pertains to the hypothesis $c=-1$. A value of $\mathrm{p}<0.05$ indicates a significant difference from -1 (1-tailed test)

\begin{tabular}{|lccccc|}
\hline Element & $T\left({ }^{\circ} \mathrm{C}\right)$ & $C( \pm \mathrm{SE})$ & $\mathrm{r}^{2}$ & $t$ & $\mathrm{p}$ \\
\hline$\delta^{13} \mathrm{C}$ & 13 & $-0.79 \pm 0.250$ & 0.91 & 0.84 & 0.21 \\
& 18 & $-1.34 \pm 0.480$ & 0.58 & 0.71 & 0.46 \\
$\delta^{15} \mathrm{~N}$ & 13 & $-1.00 \pm 0.220$ & 0.94 & 0.00 & 0.50 \\
& 18 & $-1.14 \pm 0.340$ & 0.62 & 0.41 & 0.66 \\
\hline
\end{tabular}

nential changes in isotopic composition were attributable to the production of new tissues. A nonlinear regression produced estimates of $c$ that were not significantly different from -1 (Table 4 ). This indicates that it was the production of new tissues after the diets were changed that caused the corresponding shift in the isotopic composition of the fish, rather than the turnover of existing tissues.

The nitrogen-isotopic composition of fish sampled at $t_{0}$ did not resemble values that were predicted based upon a fractionation factor of 3 to $4 \%$ between trophic levels. Based on the isotopic composition of rotifers at $t_{0}$ of $\delta^{15} \mathrm{~N}=-8 \%$ (Table 2 ), the fish at $t_{0}$ were predicted to have $\delta^{15} \mathrm{~N}$ values between -5 and $-4 \%$, but instead these were approximately $-2 \%$ o (Fig. 1a,b). This represents a fractionation of roughly $+6 \%$ o between trophic levels. The nitrogen-isotopic compositions of fish sampled at $t_{16}$ also were not in the range of what was predicted based on the isotopic composition of Artemia sp., which had a $\delta^{15} \mathrm{~N}=12.8 \%$ at $t_{16}$ (Table 2). These fish were predicted to have $\delta^{15} \mathrm{~N}$ values between 15.8 and $16.8 \%$, but instead these were approximately $12.5 \%$ in the $18^{\circ} \mathrm{C}$ treatment (Fig. 1a) and $15 \%$ in the $13^{\circ} \mathrm{C}$ treatment (Fig. 1b), for fractionation factors of -0.3 and $+2.2 \%$ respectively.

The carbon-isotopic composition of fish sampled at $t_{0}$ was different from that was predicted based upon a fractionation factor of 1 to $2 \%$ between trophic levels. Based on the isotopic composition of rotifers at $t_{0}$ of $\delta^{13} \mathrm{C}=-14.9 \%$ (Table 2), the fish at $t_{0}$ were predicted to have $\delta^{13} \mathrm{C}$ values between -13.9 and $-12.9 \%$, but instead these were approximately $-14.9 \%$ (Fig. 1c,d). This represents a fractionation of roughly $0 \%$ between trophic levels. The carbon isotopic compositions of fish sampled at $t_{16}$ in the $13^{\circ} \mathrm{C}$ treatment also were not in the range of what was predicted based on the isotopic composition of Artemia sp., which had a $\delta^{13} \mathrm{C}=-22 \%$ at $t_{16}$ (Table 2). These fish were predicted to have $\delta^{13} \mathrm{C}$ values between -21 and $-20 \%$, but instead were approximately $-19.5 \%$ (Fig. 1d), for a fractionation factor of $+2.5 \%$. However the fish in the $18^{\circ} \mathrm{C}$ treatment had $\delta^{13} \mathrm{C}$ values of approximately $-20 \%$ (Fig. 1C), which was in line with predictions based on the carbon isotopic composition of Artemia.

\section{DISCUSSION}

These findings show the clear and predictable way in which a change in diet is reflected in the isotopic composition of the tissues of young winter flounder, and that changes in the isotopic composition at this stage of development are almost entirely attributable to the production of new tissues rather than to the metabolic turnover of existing ones. Although these findings may be affected by error from using a regression of length versus dry weight to estimate the initial dry weights, similar results were reported by Herzka \& Holt (2000), who found that shifts in the isotopic composition of larval red drum Sciaenops ocellatus also resembled predictions based on growth alone. The findings of each of these studies may be unique to the developmental stages of the fish that were used. We are currently investigating this possibility by conducting feeding experiments similar to those reported here, but evaluating multiple developmental stages from fertilized eggs to juveniles.

Metamorphosis is a major event in a fish's life history, with changes in morphology (Balon 1985, Youson 1988), physiology (Marshall et al. 1937, de Silva 1974), and behavior (Sette 1943, Bergman et al. 1988). Furthermore, a large amount of energy is used during metamorphosis that might otherwise be used for growth (Balon 1985). Some authors have reported reduced and negative growth rates to be associated with this event (Ahlstrom 1968, Balon 1985, Youson 1988). One might expect, therefore, that during metamorphosis, changes that occur in the isotopic composition of fishes as a result of a change in diet would happen primarily through the turnover of existing tissues. Our findings showed conclusively that this is not true.

Biochemical reactions of poikilotherms are reduced at low temperatures (Laurence 1975, Schmidt-Nielsen 1975), and this is the likely cause of both the lower growth rates and slower changes in isotopic composition of both carbon and nitrogen observed at $13^{\circ} \mathrm{C}$ compared to $18^{\circ} \mathrm{C}$ (Fig. 2). Numerous previous studies have shown that water temperature directly affects the developmental rate of early life-history stages of various fishes (Blaxter 1969). Given the finding that the change in isotopic composition was almost entirely attributable to growth rather than metabolic turnover, it is not surprising that the fish in the $13^{\circ} \mathrm{C}$ treatment had both lower growth rates and slower rates of 
change in their isotopic compositions compared to fish in the $18^{\circ} \mathrm{C}$ treatment.

The rapid shift in isotopic composition with a diet shift in recently settled winter flounder reported here contributes toward a general understanding of the dependency of isotopic shifts on turnover rate, growth rate and, potentially, the life stages of fishes. Using similar methods, Bosley (1998) determined the carbon and nitrogen turnover rates for 3 species of juvenile fishes: striped bass Morone saxatilis, tautog Tautoga onitis, and winter flounder. The half-lives of muscle tissue were ca. 1 to $17 \mathrm{~d}$ for carbon and 2 to $19 \mathrm{~d}$ for nitrogen. In contrast, Hesslein et al. (1993) found the half-lives of carbon and nitrogen in adult whitefish to be $>1 \mathrm{yr}$. The slower turnover rates in adult whitefish may reflect the slowing of growth and metabolism in fish at advanced ages.

The fish in this experiment were found to have isotopic compositions that were different from what was predicted from the isotopic compositions of their diets using commonly accepted fractionation factors between consumers and prey. This has increasingly been the case in controlled experiments focusing on fractionation of stable isotopes. Fractionation that occurs between trophic levels has been shown to vary significantly at the primary producer level for both nitrogen (Waser et al. 1999) and carbon (Burkhardt et al. 1999). Adams \& Sterner (2000) also found a strong linear relationship between the $\mathrm{C}: \mathrm{N}$ of algae and ${ }^{15} \mathrm{~N}$ enrichment in Daphnia magna which consumed the algae, ranging from nearly zero to approximately $6 \%$. Herzka \& Holt (2000) determined a fractionation range between 0.2 and $1.9 \%$ for carbon and between 1.5 and $4.2 \%$ for nitrogen for larval red drum Sciaenops ocellatus that was independent of larval size. Finally, speciesspecific (Bosley 1998, Focken \& Becker 1998) and dietspecific (Gorokhova \& Hansson 1999) fractionation has also been reported. It is possible that the differences that were observed in fractionation in the present study may be attributable to variation in the isotopic composition of the diets. Furthermore, it is also possible that the fish that were sampled at the end of this study might not yet have reached equilibration with their new diet. Together, all of this points to the need for continued investigations into the sources of variation in fractionation. The feeding study mentioned above that is currently underway will also examine ontogenetic variation in isotopic fractionation.

The results of this study support the use of stableisotope ratios for studying diet shifts of winter flounder over relatively short periods of time (days to weeks), such as the initiation of feeding by larval fish and subsequent shifts in prey consumed. To the extent that habitat utilization is reflected in a fish's diet, stable isotopes also may be useful indicators of both the use of, and shifts between, different habitats (Herzka et al. 2001). For example, if a larval winter flounder which had been feeding in a pelagic food web since firstfeeding settled into a demersal habitat and began feeding on benthic food, the present study indicates that the tissues of that fish would reflect the habitat change within 2 to $4 \mathrm{~d}$. With the underpinnings of a validation study such as that reported here, habitat utilization can be inferred more confidently from the stable-isotopic composition of wild-caught fish.

Acknowledgements. We thank Dr. Joe Brown and the staff at the Ocean Sciences Centre, Memorial University of Newfoundland, Canada, for supplying the winter flounder eggs for this study. We also thank Heather Hamlin, Stephen Lewis, and Michelle Walsh at the NOAA Howard Laboratory, Highlands, New Jersey, for their contributions in the laboratory, and Professor Karen Bosley for editorial comments. The anonymous reviewers provided valuable comments that improved this manuscript considerably. This work was supported by funds from the NOAA Cooperative Marine Education and Research program (CMER Project \# 96-05) and by the Northeast Fisheries Science Center of the National Marine Fisheries Service. This is contribution 2002-1 of the Institute of Marine and Coastal Sciences, Rutgers University.

\section{LITERATURE CITED}

Adams TS, Sterner RW (2000) The effect of dietary nitrogen content on trophic level ${ }^{15} \mathrm{~N}$ enrichment. Limnol Oceanogr 45:601-607

Ahlstrom EH (1968) Review of 'Development of fishes of the Chesapeake Bay region, an atlas of egg, larval, and juvenile stages, part 1.' Copeia 1968:648-651

Balon EK (1985) The theory of saltatory ontogeny and life history models revisited. In: Balon EK (ed) Early life histories of fishes. Dr W Junk Publishers, Dordrecht, p 13-30

Bergman MJN, van der Veer HW, Zijlstra JJ (1988) Plaice nurseries: effects on recruitment. J Fish Biol 33:201-218

Blaxter JHS (1969) Development: eggs and larvae. In: Hoar WS, Randall DJ (eds) Fish physiology, Vol 3. Academic Press, New York, p 177-252

Bosley KL (1998) Tissue turnover of carbon and nitrogen in juvenile fish, estimated with stable-isotope ratios, and the effects of preservatives and acidification on the stableisotope ratios of marine animals. MS thesis, Rutgers University, New Brunswick, NJ

Brown ME (1957) Experimental studies on growth. In: Brown ME (ed) The physiology of fishes, Vol 1. Metabolism. Academic Press, New York, p 391-392

Burkhardt S, Riebesell U, Zondervan I (1999) Stable carbon isotope fractionation by marine phytoplankton in response to daylength, growth rate, and $\mathrm{CO}_{2}$ availability. Mar Ecol Prog Ser 184:31-41

Chambers RC (1997) Environmental influences on egg and propagule sizes in marine fishes. In: Chambers RC, Trippel EA (eds) Early life history and recruitment in fish populations. Chapman \& Hall, New York, p 63-102

Checkley DM (1982) Selective feeding by Atlantic herring (Clupea harengus) larvae on zooplankton in natural assemblages. Mar Ecol Prog Ser 9:245-253

Craig H (1957) Isotopic standards for carbon and oxygen and correction factors for mass spectrometric analysis of carbon dioxide. Geochim Cosmochim Acta 12:133-149 
DeNiro MJ, Epstein S (1978) Influence of diet on the distribution of carbon isotopes in animals. Geochim Cosmochim Acta 42:495-506

DeNiro MJ, Epstein S (1981) Influence of diet on the distribution of nitrogen isotopes in animals. Geochim Cosmochim Acta 45:1885-1894

de Silva C (1974) Development of the respiratory system in herring and plaice larvae. In: Blaxter JHS (ed) The early life history of fish. Springer-Verlag, Berlin, p 465-485

Focken U, Becker K (1998) Metabolic fractionation of stable carbon isotopes: implications for studies of the aquatic food webs using $\delta^{13} \mathrm{C}$ data. Oecologia 115:337-343

Fry B (1988) Food web structure on Georges Bank from stable C, N, and S isotopic composition. Limnol Oceanogr 33: $1182-1190$

Fry B, Arnold C (1982) Rapid ${ }^{13} \mathrm{C} /{ }^{12} \mathrm{C}$ turnover during growth of brown shrimp (Penaeus aztecus). Oecologia 54:200-204

Fry B, Sherr EB (1984) $\delta^{13} \mathrm{C}$ measurements as indicators of carbon flow in marine and freshwater ecosystems. Contrib Mar Sci 27:196-229

Gannes LZ, O'Brien DM, Martinez del Rio C (1997) Stable isotopes in animal ecology: assumptions, caveats, and a call for more laboratory experiments. Ecology 78:1271-1276

Gorokhova E, Hansson S (1999) An experimental study on variations in stable carbon and nitrogen isotope fractionation during growth of Mysis mixta and Neomysis integer. Can J Fish Aquat Sci 56:2203-2210

Grover JJ, Eggleston DB, Shenker JM (1998) Transition from pelagic to demersal phase in early-juvenile Nassau grouper, Epinephelus striatus: pigmentation, squamation, and ontogeny of diet. Bull Mar Sci 62:97-111

Hansson S, Hobbie JE, Elmgren R, Larsson U, Fry B, Johansson $\mathrm{S}$ (1997) The stable nitrogen isotope ratio as a marker of food-web interactions and fish migration. Ecology 78: 2249-2257

Herzka SZ, Holt GJ (2000) Changes in isotopic composition of red drum (Sciaenops ocellatus) larvae in response to dietary shifts: potential applications to settlement studies. Can J Fish Aquat Sci 57:137-147

Herzka SZ, Holt SA, Holt GJ (2001) Documenting the settlement history of individual fish larvae using stable isotope ratios: model development and validation. J Exp Mar Biol Ecol 265:49-74

Hesslein RH, Hallard K, Ramlal P (1993) Replacement of sulfur, carbon, and nitrogen in tissue of growing broad whitefish (Coregonus nasus) in response to a change in diet traced by $\delta^{34} \mathrm{~S}, \delta^{13} \mathrm{C}$, and $\delta^{15} \mathrm{~N}$. Can J Fish Aquat Sci 50: 2071-2076

Hobson KA, Clark RG (1992) Assessing avian diets using stable isotopes. I: Turnover of ${ }^{13} \mathrm{C}$ in tissues. Condor 94: 181-188

Jenkins GP (1987) Comparative diets, prey selection, and predatory impact of co-occurring larvae of two flounder species. J Exp Mar Biol Ecol 110:147-170

Laurence GC (1975) Laboratory growth and metabolism of the winter flounder Pseudopleuronectes americanus from

Editorial responsibility: Michael Landry (Contributing Editor), Honolulu, Hawaii, USA hatching through metamorphosis at 3 temperatures. Mar Biol 32:223-229

Marshall SM, Nicholls AG, Orr AP (1937) On the growth and feeding of the larval and post-larval stages of the Clyde herring. J Mar Biol Assoc UK 22:245-267

McConnaughey T, McRoy CP (1979) Food-web structure and the fractionation of carbon isotopes in the Bering Sea. Mar Biol 53:257-262

McLaren A, Avendano P (1995) Prey field and diet of larval cod on Western Bank, Scotian Shelf. Can J Fish Aquat Sci 52:448-463

Minami T (1982) The early life history of a flounder Paralichthys olivaceus. Bull Jpn Soc Sci Fish 48:1581-1588

Minigawa M, Wada E (1984) Stepwise enrichment of $\delta^{15} \mathrm{~N}$ along food chains: further evidence and the relation between $\delta^{15} \mathrm{~N}$ and animal age. Geochim Cosmochim Acta 48:1135-1140

Owens NJR (1987) Natural variations in ${ }^{15} \mathrm{~N}$ in the marine environment. Adv Mar Biol 24:390-451

Perry RI, Neilson JD (1988) Vertical distributions and trophic interactions of age-0 Atlantic cod and haddock in mixed and stratified waters of Georges Bank. Mar Ecol Prog Ser 49:199-214

Peterson BJ, Fry B (1987) Stable isotopes in ecosystem studies. Annu Rev Ecol Syst 18:293-320

Peterson WT, Ausubel SJ (1984) Diets and selective feeding by larvae of Atlantic mackerel Scomber scombrus on zooplankton. Mar Ecol Prog Ser 17:65-75

Rau GH, Mearns AJ, Young DR, Olson RJ, Schafer HA, Kaplan R (1983) Animal ${ }^{13} \mathrm{C} /{ }^{12} \mathrm{C}$ correlates with trophic level in pelagic food webs. Ecology 64:1314-1318

Schmidt-Nielsen K (1975) Animal physiology. Cambridge University Press, London

Seber GAF, Wild CJ (1989) Nonlinear regression. John Wiley \& Sons, New York

Sette OE (1943) Biology of the Atlantic mackerel, Scomber scombrus, of North America. Fish Bull (Wash DC) 38: $149-236$

Tieszen LL, Boutton TW, Tesdahl KG, Slade NA (1983) Fractionation and turnover of stable carbon isotopes in animal tissues: implications for $\delta^{13} \mathrm{C}$ analysis of diet. Oecologia 57 : $32-37$

Waser NA, Yu Z, Yin K, Nielsen B, Harrison PJ, Turpin DH, Calvert SE (1999) Nitrogen isotopic fractionation during a simulated diatom spring bloom: importance of N-starvation in controlling fractionation. Mar Ecol Prog Ser 179: 291-296

Witting DA (1995) Settlement of winter flounder, Pleuronectes americanus, in a southern New Jersey estuary: spatial and temporal dynamics and the effect of decapod predation. PhD thesis, Rutgers University, New Brunswick, NJ

Youson JH (1988) First metamorphosis. In: Hoar WS, Randall DJ (eds) Fish physiology, Vol 2. The physiology of developing fish. Part A. Eggs and larvae. Academic Press, London, p 135-196

Submitted: April 18, 2001; Accepted: December 27, 2001 Proofs received from author(s): June 7, 2002 